\title{
EFFECT OF L-TYROSINE DURING EARLY POSTPARTUM PERIODS ON MILK YIELD AND REPRODUCTIVE PERFORMANCE OF FRIESIAN COWS Abu El-Hamd, M. A. ${ }^{1}$; Sh. A. Gabr ${ }^{2}$ and M. S. Sayah ${ }^{1}$ ${ }^{1}$ Animal Production Res. Inst., Agric. Res. Center, Dokki, Egypt. ${ }^{2}$ Animal Production Dept., Fac. Agric., Tanta Univ.
}

\begin{abstract}
A total of 24 Friesian cows between the $1^{\text {st }}$ and $3^{\text {rd }}$ parity and average body weight (LBW) of $512.6 \pm 15.5 \mathrm{~kg}$ were divided into three similar groups ( $n=8$ each) based on their BW, parity and milk production of the previous season. Cows of the $1^{\mathrm{st}}$ group (G1) were fed concentrate feed mixture (CFM) (control group). Cows of the $2^{\text {nd }}$ group were received oral dose L-tyrosine $50 \mathrm{~g} / \mathrm{cow}$ at 21 day (G2) while those of the $3^{\text {rd }}$ group (G3) were received the same dose of G2 but on day 40 . Throughout the experimental period, cows were machine milked and daily milk yield was individually recorded for the $1^{\text {st }}$ four months. Milk composition and somatic cell count were determined. Estrus was detection and cows in heat were inseminated. Also, number and length of estrous cycles from calving up to conception were recorded. Postpartum $1^{\text {st }}$ ovulation (PPOI), $1^{\text {st }}$ estrus (PPEI) and $1^{\text {st }}$ service (PPSI) intervals, number of services per conception (NSC), days open (DO) and conception rate (CR\%) were calculated. Pregnancy was diagnosed by rectal palpation on day 60 postinsemination.

Results revealed that $L$-tyrosine treatment improved $(P<0.05)$ daily milk production of $\mathrm{G} 2$ and $\mathrm{G} 3$ by 15.6 and $16.3 \%$ compared to $\mathrm{G} 1$. $\mathrm{G} 3$ had higher $(\mathrm{P}<0.05)$ percentages of fat, protein and lactose as compared to $\mathrm{G} 1$ (3.64, 3.07 and $4.16 \mathrm{vs}$. $3.54,2.75$ and $4.00 \%)$, respectively. $G 2$ had higher $(P<0.05)$ percentages of protein and lactose (2.98 and $4.28 \%$, respectively) compared to $\mathrm{G} 1$, while fat percentage was similar to G1. Treated cows with $\mathrm{L}$-tyrosine showed lower $(\mathrm{P}<0.05)$ somatic cell count in milk as compared to $\mathrm{G} 1$.

Postpartum estrous interval was shorter $(P<0.05)$, by 11.5 days in $G 2$ than G1, While, those of G3 showed longer period (+ 8.13 day) than G1. Days open in $G 2$ and $\mathrm{G} 3$ cows was shorter $(\mathrm{P}<0.05)$ by 21 or 13.2 day, respectively, than $\mathrm{G} 1$. Number of services per conception was less $(P<0.05)$ in $G 2(1,63)$ and $G 3(2.0)$ than in $G 1$ (2.6). Conception rate increased $(P<0.05)$ in $\mathrm{G} 2$ and $\mathrm{G} 3$ compared with those of control (50 vs. 75 and $100 \%$ ).

Keywords: Friesian, lactation, L-tyrosine, milk yield, reproduction.
\end{abstract}

\section{INTRODUCTION}

Use of organic substances is believed having positive effect on animal productivity and reproductive performance through enhancing the release of sex hormones (Gabr, 2009). One of these substances is Ltyrosine, which involves in the catecholamine and thyroxin formation (Hammel and Russe, 1987). In addition it serves as a precursor for the synthesis of dopamine, norepinephrine, and epinephrine and is a specific brain neurotransmitter implicated in the control of GnRH and LH (Ramirez et al., 1984). 
Abu El-Hamd M. A. et al.

Tyrosine may be involved in stimulating $\mathrm{GnRH}$ via influencing synthesis of norepinephrine (Gibson and Wurtman, 1986 and Acworth et al., 1988), a neurotransmitter that stimulates $\mathrm{GnRH}$ release (Ramirez et al., 1984 and Terasawa et al., 1988).

The relationship between tyrosine and reproduction has been reported previously (Gabr, 2009). In dairy cows, tyrosine treatment resulted in expressing estrus within several days in more than $85 \%$ of the cows followed by normal estrous cycles (Munsterer, 1987).

In sows, exogenous tyrosine increased LH pulse frequency in growth-restricted lambs (Hall et al., 1992), induced follicular growth, estrus and ovulation in anovulatory dairy cows (Hammerl, 1986 and Munsterer, 1987) and improved expression of estrus (Hammerl and Russe, 1987).

The aim of the present work was to study the effect of post-partum L-tyrosine treatment on milk yield and reproductive performance of Friesian cows during the first four months postpartum.

\section{MATERIALS AND METHODS}

The present study was carried out at Sakha Animal Production Research Station, belonging to the Animal Production Research Institute, Agricultural Research Center, Ministry of Agriculture and Land Reclamation, Egypt during the period from July to November 2009.

Animals and management:

A total of 24 health Friesian cows with an average of $512.6 \pm 15.5 \mathrm{~kg}$ body weight (BW), between 28 and 56 months of age and 1-3 parities was used in this study. All cows were chosen at early postpartum period (10 days post calving). At the beginning of the experimental period, the experimental cows were divided into three similar groups, 8 in each. Mutiparous cows $(n=5$ in each group) were divided according to their BW, parity and milk production of the previous season, while primiparous cows ( $n=3$ in each group) were allotted based only on their BW.

Experimental cows were fed according to their BW and milk production. The $1^{\text {st }}$ group (G1) was served as a control, while cows in $2^{\text {nd }}$ (G2) and $3^{\text {rd }}(\mathrm{G} 3)$ groups were received an oral dose of L-tyrosine (50 g/cow) at day 21 and 40 of postpartum period, respectively. All cows were housed in separately semi-open yards .

\section{Feeding system:}

Experimental cows were fed a diet containing concentrate feed mixture, rice straw and corn silage according to the recommendation of NRC (2001) for dairy cows based on their live body weight and milk yield.

\section{Experimental procedures:}

\section{Milk yield and composition:}

Cows were machine milked twice daily at 6:00 and 17:00 h. Daily milk yield (morning and evening) was individually recorded for the $1^{\text {st }}$ four months of lactation. Milk samples were monthly collected to determine milk composition using Milko-Scan (Model 133B) and somatic cell count (Foss Electronic 360, Slangerupgade, Denmark). 


\section{Detection of estrus and insemination:}

Beginning of day 10 postpartum, an infertile bull was introduced to cows of each group for 20 minutes three times daily at 6,12 and $15 \mathrm{~h}$ to recognize the onset of the $1^{\text {st }}$ estrus. Estrus was identified when cows showed complete receptivity to the teaser and stood quietly to be mounted. Cows those be recognized to be on heat were artificially inseminated.

Number and length of estrous cycles from calving up to conception were recorded. Postpartum $1^{\text {st }}$ ovulation ( PPOI), $1^{\text {st }}$ estrus (PPEI) and $1^{\text {st }}$ service (PPSI) intervals, number of services per conception (NSC), days open (DO) and conception rate (CR\%) were calculated. Conception rate was calculated as the proportion of Conceived cows relative to inseminated cows multipliable by 100 .

Pregnancy was diagnose by rectal palpation which taken place on day 60 post-insemination.

\section{Statistical analysis:}

The obtained data were statistically analyzed using SAS (1990). The significant differences among treatment groups were tested using Duncan's Multiple Range Test (Duncan, 1955). The statistical model was

Where:

$$
Y_{i j}=U+A_{i}+e_{i j} \text {. }
$$

$Y_{i j}=$ Observed traits

$\mathrm{U}=$ Overall mean

$A_{i}=$ Experimental group 1-3 (1= G1, 2= G2 and 3=G3)

$\mathbf{e}_{\mathrm{ij}}=$ Random error

Conception rate values were statically analyzed using Chi square test.

\section{RESULTS AND DISCUSSION}

\section{Milk yield:}

L-tyrosine treatment in $\mathrm{G} 2$ and $\mathrm{G} 3$ increased $(\mathrm{P}<0.05)$ daily milk production during the $1^{\text {st }}$ four months of lactation, compared to $G 1$ (Table 1). It is of interest to note that treatment of L-tyrosine on 21 (G2) or 40 (G3) daypostpartum improved $(\mathrm{P}<0.05)$ protein and lactose percentages as compared to G1. This however, treatment on day 40 postpartum (G3) affected fat percentage compared to $\mathrm{G} 1$. This indicates that L-tyrosine treatment has a positive reflection on the yield of fat and protein (Table 1). Meanwhile it reduces $(P<0.05)$ the somatic cell count.

The present results come in agreement with the findings of Rae and Ingalls (1984) reporting an increase in milk production as a result of tyrosine treatment. This is mostly attributed to the increase in blood supply (Mepham, 1982 ) and the energy intake of mammary gland cells (Anderson, 1979 and Wurtman, 1982), in addition to its effect on increasing growth hormone via its effect on brain catecholamine's (Martin, 1980). This explanation is supported by the previous findings of Machlin (1973) and Peel et al. (1981) who found that administration of exogenous growth hormone increases milk production. 
Abu El-Hamd M. A. et al.

The observed increase in milk protein yield in treated groups may be attributed to elevation in the supply of tyrosine to the mammary gland, to from milk protein (Mepham, 1982).

Table (1): Yield and composition of milk (Mean \pm MSE) as affected by time of L-tyrosine treatment as calculated throughout the first 120 day post-partum.

\begin{tabular}{|c|c|c|c|c|}
\hline \multirow{2}{*}{ Item } & \multicolumn{3}{|c|}{ Experimental groups $(\mathrm{n}=8)$} & \multirow{2}{*}{ \pm MSE } \\
\hline & $\overline{\mathbf{G 1}}$ & G2 & G3 & \\
\hline \multicolumn{5}{|c|}{ Average daily milk yield (kg/day): } \\
\hline Actual milk yield & $13.5^{b}$ & $15.6^{\mathrm{a}}$ & $15.7^{\mathrm{a}}$ & 0.25 \\
\hline $4 \%$ fat corrected milk & $12.6^{\mathrm{b}}$ & $14.3^{\mathrm{a}}$ & $14.9^{\mathrm{a}}$ & 0.22 \\
\hline \multicolumn{5}{|l|}{ Milk composition (\%): } \\
\hline Fat & $3.54^{\mathrm{ab}}$ & $3.46^{b}$ & $3.64^{\mathrm{a}}$ & 0.038 \\
\hline Protein & $2.75^{b}$ & $2.98^{\mathrm{a}}$ & $3.07^{\mathrm{a}}$ & 0.045 \\
\hline Lactose & $4.0^{b}$ & $4.23^{a}$ & $4.16^{\mathrm{a}}$ & 0.039 \\
\hline \multicolumn{5}{|l|}{ Component yields (g/day): } \\
\hline Fat & $47.8^{\mathrm{b}}$ & $54.0^{\mathrm{ab}}$ & $57.1^{\mathrm{a}}$ & 2.94 \\
\hline Protein & $37.1^{\mathrm{D}}$ & $46.5^{\mathrm{a}}$ & $48.2^{a}$ & 4.34 \\
\hline Lactose & $54.0^{\mathrm{D}}$ & $66.0^{\mathrm{a}}$ & $65.3^{a}$ & 3.21 \\
\hline Somatic cell count $\left(10^{3} / \mathrm{ml}\right)$ : & $374.56^{\mathrm{a}}$ & $296.12^{b}$ & $275.43^{b}$ & 20.4 \\
\hline
\end{tabular}

a and : Means within the same row with different superscripts are significantly different $(P<0.05)$.

G1= Control, G2= Cows received oral dose of L-tyrosine $(50 \mathrm{~g} / \mathrm{cow})$ at day 21 of postpartum period and G3= Cows received oral dose of L-tyrosine $(50 \mathrm{~g} / \mathrm{cow})$ at day 40 of postpartum period.

\section{Reproductive traits:}

Data in Table (2) indicated that G2 showed the significantly shorter PPEI and DO, in addition lower NS/C and the highest CR compared to G1 and G3. Except PPEI, which was the longest in G3, the other reproductive traits of $\mathrm{G} 3$ came between $\mathrm{G} 1$ and $\mathrm{G} 2$.

Table (2): Reproductive traits (Mean \pm MSE) as affected by time of Ltyrosine treatment throughout the first 120 days post-partum

\begin{tabular}{|c|c|c|c|c|}
\hline \multirow{2}{*}{ Item } & \multicolumn{3}{|c|}{ Experimental groups $(n=8)$} & \multirow{2}{*}{ \pm MSE } \\
\hline & G1 & G2 & G3 & \\
\hline Postpartum $1^{\text {st }}$ estrus interval (day) & $38.0^{\mathrm{b}}$ & $26.5^{\mathrm{C}}$ & $46.13^{\mathrm{a}}$ & 1.60 \\
\hline Number of services per conception & $2.60^{\mathrm{a}}$ & $1.60^{b}$ & $2.00^{\mathrm{ab}}$ & 0.30 \\
\hline Days open (day) & $81.0^{\mathrm{a}}$ & $60.0^{\mathrm{b}}$ & $67.8^{\mathrm{ab}}$ & 6.10 \\
\hline Conception rate (\%) & $50^{c}$ & $100^{\mathrm{a}}$ & $75^{\mathrm{b}}$ & - \\
\hline
\end{tabular}

and b: Means within the same row with different superscripts are significantly different $(P<0.05)$.

Such trend is in agreement with the results of Hammerl (1986) in which reported higher conception rate (69\%) after treating anestrous cows with L-tyrosine compared to $26 \%$ in the control group. This may be due to the involvement of tyrosine in stimulating $\mathrm{GnRH}$ release via stimulating synthesis of norepinephrine (Wurtman et al., 1981; Gibson and Wurtman, 1986 and Acworth et al., 1988), and /or neurotransmitter that stimulates $\mathrm{GnRH}$ release (Ramirez et al., 1984 and Terasawa et al., 1988). 


\section{Ovarian activity:}

Results in Table (3) showed that L-tyrosine treatment in G2 and G3 decreased $(P<0.05)$ average number of estrus cases and ovulatory cycles per cow during the ovulatory cycles compared with the control group. On the other hand, the no statistical differences in average number of total ovulations, silent ovulations per cow, ovulatory cycle length during the ovulatory cycles were observed among experimental groups.

The low number of estrus per cow was associated with that exogenous tyrosine treatment induced follicular growth and ovulation in anovulatory dairy cows (Wetzel, 1985; Hammerl, 1986 and Munsterer, 1987).

Table (3): Postpartum ovarian activity and progesterone (P4) concentration of cows in different experimental groups.

\begin{tabular}{|l|c|c|c|c|}
\hline \multirow{2}{*}{\multicolumn{1}{|c|}{ Item }} & \multicolumn{2}{|c|}{ Experimental group (n=8) } & \multirow{2}{*}{ IMSE } \\
\cline { 2 - 5 } & G1 & G2 & G3 & \\
\hline Total number of ovulations/cow & 4.00 & 3.00 & 3.25 & 0.43 \\
\hline Number of silent ovulations/cow & 0.75 & 0.00 & 1.00 & 0.36 \\
\hline Total number of estrus cases & $3.50^{\mathrm{a}}$ & $2.50^{\mathrm{b}}$ & $2.25^{\mathrm{b}}$ & 0.29 \\
\hline Number of ovulatory cycles/cow & $3.50^{\mathrm{a}}$ & $2.25^{\mathrm{b}}$ & $2.50^{\mathrm{b}}$ & 0.24 \\
\hline Ovulatory cycle length (day) & 20.64 & 21.25 & 22.67 & 3.61 \\
\hline
\end{tabular}

L-tyrosine may involve stimulation of $\mathrm{GnRH}$ release because availability of tyrosine influences synthesis of norrepenephrine (Wurtman et al., 1981), a neurotransmitter that stimulates hypothalamic $\mathrm{GnRH}$ release and pulsatile and preovulatory release of $\mathrm{LH}$ from pituitary gland (Ramiez et al., 1984 and Terasawa et al., 1988). The catecholamines may mediate effects of other neurotransmitters and gonadal steroids on release of $\mathrm{GnRH}$ (Kalra and Kalra, 1983; Ramirez et al., 1984 and Yen and Vale, 1990).

In conclusion, the present study indicated the beneficial effects of Ltyrosine treatment on day 21 post-partum on milk yield and reproductive performance of Friesian cows during the first four months of lactation.

\section{REFERENCES}

Acworth, I. N., M. J. During, and R. J. Wurtman (1988). Tyrosine: Effects on catecholamine release. Brain Res. Bull., 21:473 $\square 477$.

Anderson, G. H. (1979). Control of protein and energy intake: role of plasma amino acids and brain neurotransmitters. Can. J. Physiol. Pharmacol., 57:1043.

Duncan, D. B. (1955). Multiple rang and multiple F test. Biometrics 11: 1-42.

Gabr, Sh. A. (2009). The relay of sexual puberty in rabbit male by $L-$ tyrosine or carnitine treatment . J. Agric. Res. Kafrelsheikh Univ., 35 (1).

Gibson, C. J., and R. J. Wurtman. (1986). Physiological control of brain norepinephrine synthesis by brain tyrosine concentrations. Life Sci., 22:1399-1406. 
Hall, J. B., K. K. Schillo, S. M. Hileman, and J. A. Boling (1992). Does tyrosine act as a nutritional signal mediating the effects of increased feed intake on luteinizing hormone patterns in growth-restricted lambs? Biol. Reprod., 46: 573-579.

Hammerl, J. (1986). Der Einfluß der Aminosauren L-Tyrosin, als ein Katecholamin-Vorla"ufer, auf die Reproduktion bei Kuhen. In: Proc. 14th World Cong. on Diseases of Cattle. Vol 2. p 911. Dublin, U.K.

Hammerl, J., and M. Russe (1987). Reproduktionssteigerung bei Sauen durch perorale Verabreichung von L-Tyrosin. Tieraerztl. Umsch. 42: $551-554$

Kalra, S. P. and P. S. Kalra (1983). Neural regulation of luteinizing hormone secretion in the rat. Endocr. Rev., 4:311.

Machlin, L. J. (1973). Effect of growth hormone on milk production and feed utilization in dairy cows. J. Dairy Sci., 56:575.

Martin, J. B. (1980). Functions of central nervous system neurotransmitters in regulation of growth hormone secretion. Fed. Proc. 39:2902.

Mepham, T. B. (1982). Amino acid utilization by lactating mammary gland. J. Dairy Sci. 65:287.

Munsterer, P. (1987). Zur Anwendung der Aminosaure L-Tyrosin in der Sterilitatsbehandlung des Milchrindes. Vet. Dissertation. Univ. of Munich, Germany.

NRC (2001). National Research Council, Nutrient Requirements of Dairy Cattle. 7th rev. ed. National Academy Press, Washington, DC.

Peel, C. J., D. E. Bauman, R. C. Gorewit, and C. J. Sniffen (1981). Effect of exogenous growth hormone on lactational performance in yielding dairy cows. J. Nutr. 111:1662.

Rae R. C. and J. R. Ingalls (1984). Lactational response of dairy cow to oral administration of L-tyrosine. J. Dairy Sci., 68: 1430-1438.

Ramirez, V. D., H. H. Feder, and C. H. Sawyer (1984). The role of brain catecholamines in the regulation of LH secretion: A critical inquiry. In: L. Martini and W. F. Ganong (Ed.) Frontiers in Neuroendocrinology (Vol. 8). p 27. Raven Press, New York.

SAS (1990). SAS user's guide. Statistical Analysis System. Institute, Inc. Cary., NC.

Terasawa, E., C. Krook, D. L. Hei, M. Gearing, N. J. Schultz, and G.A. Davis (1988). Norepinephrine is a possible neurotransmitter stimulating pulsatile release of luteinizing hormone releasing hormone in the rhesus monkey. Endocrinology, 123: 1808-1816.

Wetzel, G. (1985). Der Einfluß der Aminosa"ure L-Tyrosin auf das Fruchtbarkeitsgeschehen beim Rind. Vet. Dissertation. Univ. of Munich, Germany.

Wurtman, R. J. (1982). Nutrients that modify brain function. Sci. Am., 246:5059.

Wurtman, R.J., F. Hefti, and E. Melamed (1981). Precursor control of neurotransmitter synthesis. Pharmacol. Rev., 32: 315-335. 
Yen, S.S.C. and W. V. Vale (Ed.) (1990). Neuroendocrine regulation of reproduction. In: Proc. Symp. Neuroendocrine Regulation of Reproduction, November 5-9, 1989, Napa, CA, Serono Symposia, USA, Nonvell.

تأثير التيروزين على إنتاج اللبن والصفات التتاسلية أثناء فترة بعد الولادة المبكرة

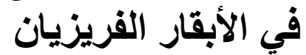

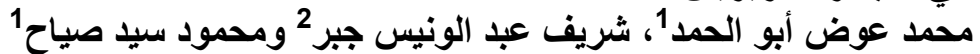

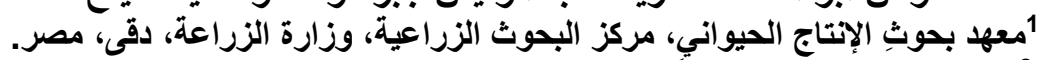

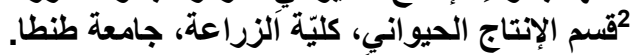

أستخدم في هذه الدراسة 24 بقرة فريزيان متوسط أوزانها

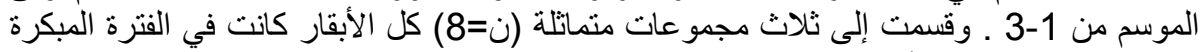

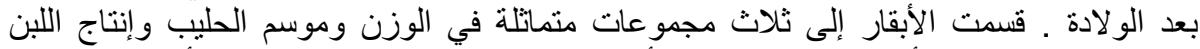

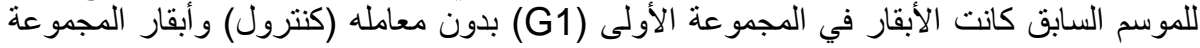

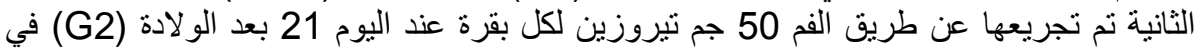

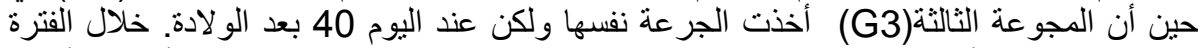

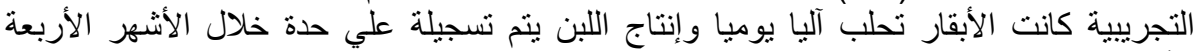

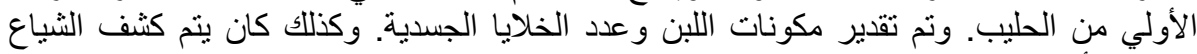

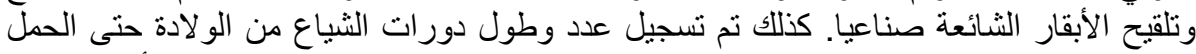

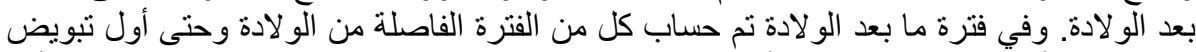

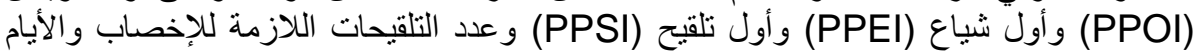

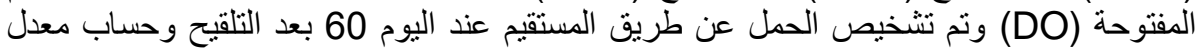

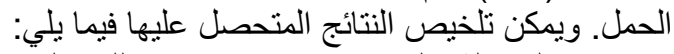

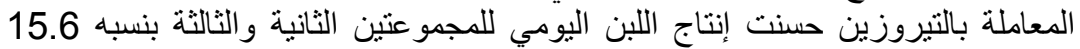

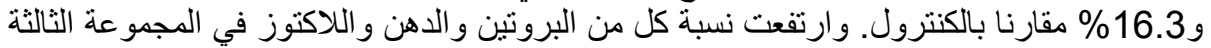

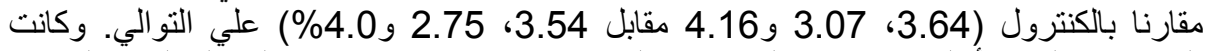

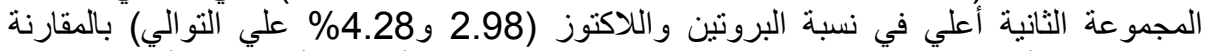

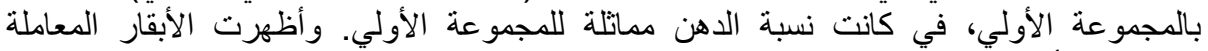

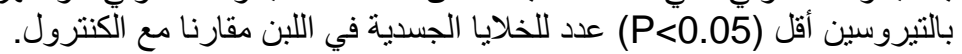

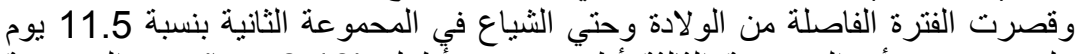

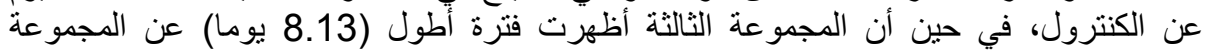



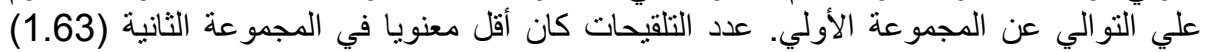

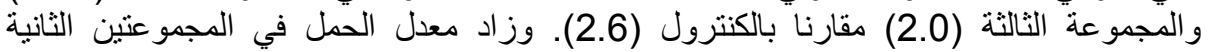
و الثالثة بالمقارنة بالكنترول (50) مقابل 75 و 100\%ة (20).

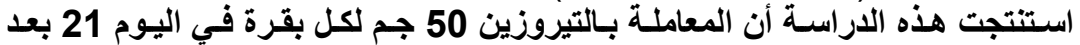
الولادة حسنت إنتاج اللبن والأداء التناسلي للأبقار الفريزيان خلال الأثنهر الأربعة الأولي من إنتاج

كلية الزراعة - جامعة المنصورة كلية الزراعة - جامعة القاهرة
قام بتحكيم البحث

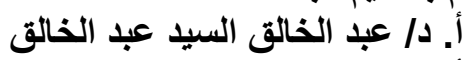

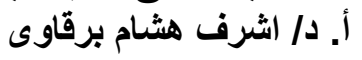

